DGGS publications are available at:

3601 C St (10th fl.)

Pouch $7-005$

Anchorage, 99510

P.O. Box 7438

State Office Bldg.

Ketchikan, 99901

794 University Ave.

(Basement)

Fairbanks. 99701

400 Willoughby Center (4th fl.)

Juneaw, 99801

\section{STATE OF ALASKA AEROMAGNETIC SURVEYS}

Revised December 15, 1984
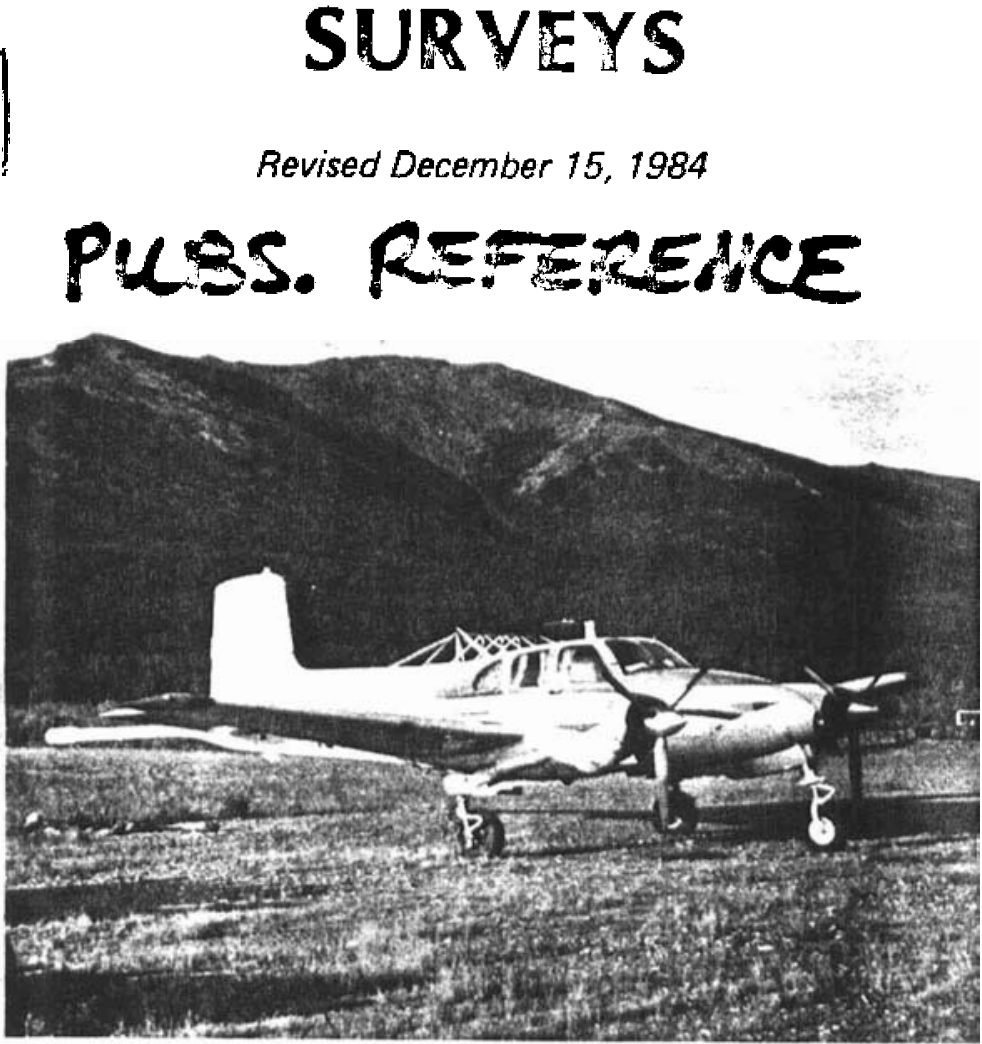

INFORMATION CIRCULAR 20
Property of DGGS LIBRARY

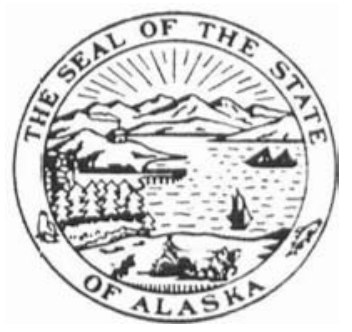

STATE OF ALASKA

Bill Sheffield, Governor Esther C. Wunnicke, Commissioner,

Dept. of Natural Resources

Ross G. Schaff, State Geologist

\section{ALASKA}

DIVISION OF GEOLOGICAL \& GEOPHYSICAL SURVEYS 
STATE OF ALASKA

\section{Department of Natural Resources DIVISION OF GEOLOGICAL \& GEOPHYSICAL SURVEYS}

According to Alaska Statute 41 , the Alaska Division of Geological and Geophysical Surveys is charged with conducting 'geological and geophysical surveys to determine the potential of Alaska lands for production of metals, minerals, fuels, and geothermal resources; the locations and supplies of ground water and construction materials; the potential geologic and seismic hazards to buildings, roads, bridges, and other installations and structures; and shall conduct other surveys and investigations as will advance knowledge of the geology of Alaska.'

In addition, the Division shall collect, evaluate, and publish data on the underground, surface, and coastal waters of the state. It shall also acquire, process, and file data from well-drilling logs.

DGGS performs numerous functions, all under the direction of the State Geologist-resource investigations (including mineral, petroleum, geothermal, and water), geologic-hazard and geochemical investigations, and information services.

Administrative functions are performed under the direction of the State Geologist, who maintains his office in Anchorage. DGGS of fices are at:

.794 University Ave. (Basement)

Fairbanks, 99701

(907) 474-7147

.400 Willoughby Center (4th floor)

Juneau, 99801

(907) $465 \cdot 3400$
$.3601 \mathrm{C} \mathrm{St}(8 \mathrm{th} \mathrm{fl})$

Pouch 7-028

Anchorage, 99510

(907) 276-2653

P.O. Box 772116

Eagle River, 99577

(907) 688-3555

Cover: Beechcraft Twin Bonanza used in aeromagnetic survey, 1972. Note magnetometer boom extending from tail. 


\section{STATE OF ALASKA AEROMAGNETIC SURVEYS}

For several years, the Division of Geological and Geophysical Surveys has published maps of aeromagnetic surveys to encourage additional planned development of Alaska's natural resources and to add to the basic geologic knowledge of the state.

DGGS produces two types of aeromagnetic maps: $1: 63,360$-scale maps of U.S. Geological Survey (USGS) 15-minute quadrangle subdivisions and 1:250,000-scale maps of entire quadrangles (fig. 1). All maps may be examined at any of the offices listed on the back cover.

Survey flight lines to collect data for the maps were spaced $3 / 4$ to 1 mile apart and 1,000 feet above ground level where possible. Tie lines were flown at 15 -mile intervals normal to the flight lines. The fluxgate-magnetometer signal was recorded in flight on a paper strip-chart recorder. Post-1975 data were recorded with a proton magnetometer digitized on 3/8-mile centers. The total magnetic-field intensities at each center were recorded on magnetic tape. Altitude and flight position were monitored throughout each survey. Aerial photographs---at 3-second intervals on 35-mm black-and-white film---were used to plot the aircraft path. The regional field was removed from the magnetic data with the 1965 or 1975 IGRF updated to the year flown.

\section{1:63,360-SCALE MAPS (1 INCH EQUALS 1 MILE)}

These maps supplement knowledge of bedrock geology, particularly in extending rock boundaries in areas covered by vegetation and unconsolidated Holocene deposits. They are also useful in selecting areas for additional geophysical and geological programs and may indicate favorable conditions for identifying lithologic, structural, and economic information. The 1:63,360. scale printed maps (table 1) cost 50 cents each. Red contour lines that represent magnetic total-field intensity are superimposed on gray U.S. Geological Survey topographic quadrangles. A small number of the $1: 63,360$ scale maps (indicated by asterisk in table 1) are available only as diazo blacklines at a charge of $\$ 2$ each. 


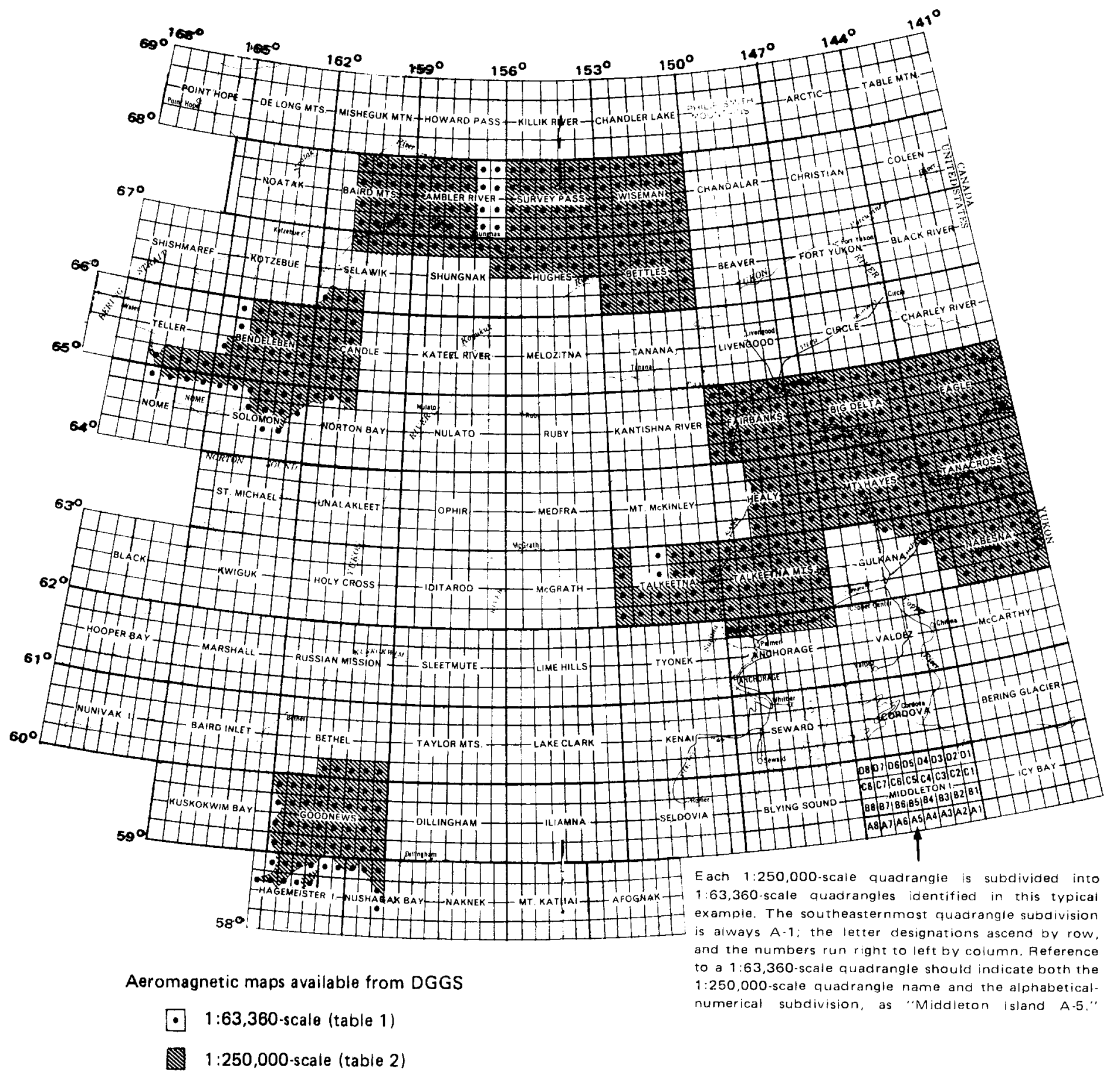

Figure 1. Index map of part of Alaska showing DGGS aeromagnetic surveys. 
Table 1. 1:63,360-scale aeromagnetic maps. is also shown on figure 1.

\begin{tabular}{ll} 
Quadrangle & Subdivision \\
\hline Ambler River & A-1 thru A-6 \\
& B-1 thru B-6 \\
C-1 thru C-6 \\
D-1 thru D-6 \\
Anchorage & D-1 thru D-8 \\
Baird Mts. & A-1 thru A-4 \\
& B-1 thru B-4 \\
C-1 thru C-4 \\
D-1 thru D-4 \\
B-1 thru A-6 \\
Bendeleben & B-1 thru B-6 \\
& C-1 thru C-5 \\
D-1 thru D-5 \\
Bethel \\
Bettles
\end{tabular}

Table 1. (con.)

\begin{tabular}{|c|c|}
\hline Healy & $\begin{array}{l}\text { A-1 thru A-4 } \\
\text { B-1 thru B-4 } \\
\text { C-1 thru C-4 } \\
\text { D-1 thru D-4 }\end{array}$ \\
\hline Hughes & $\begin{array}{l}\text { C-1 thru C-6* } \\
\text { D-1 thru D-6 }\end{array}$ \\
\hline Mount Hayes & $\begin{array}{l}\text { A-1 thru A-6 } \\
\text { B-1 thru B-6 } \\
\text { C-1 thru C-6 } \\
\text { D-1 thru D-6 }\end{array}$ \\
\hline Nabesna & $\begin{array}{l}\text { A-1 thru A-5 } \\
\text { B-1 thru B-6 } \\
\text { C-1 thru C-6 } \\
\text { D-1 thru D-6 }\end{array}$ \\
\hline Nushagak Bay & $\begin{array}{l}\text { B-4 } \\
\text { C-4 } \\
\text { D-4 thru D-6 }\end{array}$ \\
\hline Nome & D-1 thru D-4 \\
\hline Norton Bay & $D-4$ thru D-6 \\
\hline Selawik & $\begin{array}{l}\text { A-4 thru A-6 } \\
\text { D-1 thru D-4 }\end{array}$ \\
\hline Shungnak & $\begin{array}{l}\text { C-1* } \\
\text { D-1 thru D-6 }\end{array}$ \\
\hline Solomon & $\begin{array}{l}\text { B-2 thru B-3 } \\
\text { C-1 thru C-4 } \\
\text { D-1 thru D-6 }\end{array}$ \\
\hline Survey Pass & $\begin{array}{l}\text { A-1 thru A-6 } \\
\text { B-1 thru B-6 } \\
\text { C-1 thru C-6 } \\
\text { D-1 thru D-6 }\end{array}$ \\
\hline Talkeetna & $\begin{array}{l}\text { A-1 thru A-6 } \\
\text { B-1 thru B-6 } \\
\text { C-1 thru C-4 } \\
\text { C-6 } \\
\text { D-1 thru D-4 } \\
\text { D-6 }\end{array}$ \\
\hline
\end{tabular}

Talkeetna Mts.

A-1 thru A-6 B-1 thru B-6 C-1 thru C-6 D-1 thru D-6

Tanacross

A-1 thru A-6 B-1 thru B-6 C-1 thru C-6 D-1 thru D-6

Teller

A-1 thru A-4

Wiseman

A-4 thru A-6* B-2 thru B-6* C-2 thru C-6* D-2 thru D-6*

* Available only as diazo blacklines. 


\section{1:250,000-SCALE MAPS (1 INCH EQUALS 4 MILES)}

The 1:250,000-scale aeromagnetic map is a compilation of the aeromagnetic data from individual 15-minute quadrangles and shows the total magnetic-field intensity over an entire quadrangle. The 1:250,000-scale maps are part of the Division open-file-report (AOF) series and may be ordered by report number (table 2). The maps cost $\$ 2$ each.

Table 2. 1:250,000-scale aeromagnetic maps. Coverage is also shown on figure 1 .

\begin{tabular}{|c|c|}
\hline $\mathrm{AOF}$ & Quadrangle \\
\hline 1 & Selawik (SW part) \\
\hline 2 & Teller (SE part) \\
\hline 3 & Bendeleben (except NW corner) \\
\hline 4 & Candle (W half) \\
\hline 5 & Nome (NE part) \\
\hline 6 & Solomon (N part) \\
\hline 7 & Norton Bay (NW part) \\
\hline 8 & Fairbanks \\
\hline 9 & Healy (E 2/3) \\
\hline 10 & Mt. Hayes \\
\hline 11 & Tanacross \\
\hline 12 & Gulkana (NE part) \\
\hline 13 & Nabesna (except SW part) \\
\hline 14 & Bethel (SE part) \\
\hline 15 & Goodnews \\
\hline 16 & Hagemeister Is. (NE part) \\
\hline 17 & Nushagak Bay (NW part) \\
\hline 18 & Eagle \\
\hline 19 & Talkeetra \\
\hline 20 & Talkeetna Mts. \\
\hline 21 & Anchorage (N quarter) \\
\hline 73 & Big Delta \\
\hline 76 & Ambler River (W 2/3) \\
\hline 77 & Baird Mts. (E $2 / 3$ ) \\
\hline 78 & Selawik (NE part) \\
\hline 79 & Shungnak (NW part) \\
\hline 175 & Survey Pass \\
\hline 176 & Wiseman \\
\hline 177 & Shungnak (N part) \\
\hline 178 & Hughes ( $N$ half) \\
\hline 179 & Bettles \\
\hline
\end{tabular}

Additional information on federally funded aero magnetic and airborne radioactivity maps and profiles in Alaska may be obtained at:

U.S. Geological Survey, 4230 University Drive, Anchorage, AK 99508-4664 